\title{
Role of phosphodiesterase in cyclic AMP signaling in cultured rat granulosa cells*
}

\author{
Zhengchao WANG, Lingmei PAN, Jinbiao LUO, Hao WANG, \\ Fangxiong SHI** \\ Laboratory of Animal Reproduction, College of Animal Science and Technology, Nanjing Agricultural \\ University, Nanjing, 210095 China
}

(Received 13 October 2005; accepted 5 December 2005)

\begin{abstract}
Inactivation of the cyclic nucleotide signal in granulosa cells depends on a complex array of cyclic nucleotide phosphodiesterases (PDE). In order to examine the role of PDE in cyclic AMP (cAMP) signaling in granulosa cells, the present study examined the expression of PDE4D proteins and regulation of cAMP-PDE activities in cultured rat granulosa cells. The results of immunoblot analyses showed that two predominant PDE4D subtypes of approximately 80 and $70 \mathrm{kDa}$ appeared when immature rat granulosa cells were treated with FSH. However, these two new subtypes presumed to be PDE4D proteins were not influenced by treatments of DETA/NO, cGMP and PKB inhibitor, LY294002. Immature rat granulosa cells treated with medium alone displayed low cAMPPDE activity throughout $48 \mathrm{~h}$ of culture while those treated with FSH $\left(2 \mathrm{ng} \cdot \mathrm{mL}^{-1}\right)$ showed a marked increase in cAMP-PDE activity between 6 and $12 \mathrm{~h}$ of culture, followed by a decline. The findings from the present study indicate that the increased cAMP-PDE activity by FSH is mainly related to the changes of PDE4D protein levels. However, the inhibitory effects of NO on cAMP accumulation in rat granulosa cells are not via the increased cAMP-PDE activity.
\end{abstract}

phosphodiesterase / cyclic AMP / granulosa cell / nitric oxide / rat

\section{INTRODUCTION}

Cyclic AMP (cAMP) plays a critical role in the maturation of granulosa cells. The accumulation of cAMP is tightly and dynamically regulated by two major enzymes, adenylyl cyclase (AC) and phosphodiesterase (PDE), which catalyze the synthesis or degradation of cAMP, respectively. PDE are a large group of isoenzymes encoded by at least 21 different genes and organized into
10 families depending on their biochemical and pharmacological properties, such as substrate affinity (cAMP or cGMP) or sensitivity to specific inhibitors [1-3]. In the ovaries, granulosa cells are known to express the type 4 cAMP-specific PDE (PDE4D) gene, a mammalian homologue of the Drosophila dunce $[4,5]$. This isoenzyme is involved in feedback regulation of cAMP levels in the rat granulosa cells, but little is known about the regulation of PDE4D

\footnotetext{
* Supported by National Nature Science Foundation of China (No. 30571335) to FS.

** Corresponding author: fxshi@ njau.edu.cn
} 
protein levels [4]. Therefore, it is important to examine the expression and regulation of PDE4D in the rat granulosa cells.

PDE modulate the concentration of cAMP, which in turn regulates the activity of cAMP dependent protein kinase A (PKA). In addition to PKA activation, recent studies have also demonstrated that cAMP may be involved in the activation of additional kinase cascades including phosphatidylinositol 4,5-bisphosphate 3-kinase (PI-3K) and protein kinase $\mathrm{B}$ (PKB) [6-8]. Thus a novel signaling pathway involving activation of PKB may also play a pivotal role toward cell survival and proliferation in granulosa cells. However, as yet, there is little information about the relationship between PKB and PDE. Therefore, our current studies also examined the influence of the PKB inhibitor, LY294002 on PDE4D protein levels in rat granulosa cells.

Nitric oxide (NO) is an inorganic, shortlived (a few seconds) free-radical gas that, due to its high solubility, freely diffuses through biological membranes. The involvement of NO in the modulation of granulosa cell functions has been documented by several studies $[9,10]$. NO is known to influence cell functions in part through the activation of soluble guanylyl cyclase (sGC), a dimeric protein that, when activated, increases production of cGMP $[11,12]$. In this regard, the effects of NO on granulosa cells may be associated with marked increases in cGMP accumulation. However, the mechanism whereby NO affects the functions of granulosa cells still needs to be clarified. Therefore, our current studies examined the influence of the NO/cGMP system on PDE4D protein levels in rat granulosa cells.

\section{MATERIALS AND METHODS}

\subsection{Animals}

Intact, immature (age, 21 days) and adult (4-month-old) Harlan Sprague-Dawley rats (Qinglongshan Experimental Animal Sup- ply Co. Ltd, Nanjing, China) were used. The animals were maintained under a 14-h light, 10-h dark schedule with food and water available ad libitum. The experimental protocol was approved in accordance with the Guide for the Care and Use of Laboratory Animals prepared by the Institutional Animal Care and Use Committee, Nanjing Agricultural University.

\subsection{Experimental design}

Primary granulosa cell culture: immature granulosa cells were obtained from the ovaries of 25-day-old female rats treated for 5 days with subcutaneous estrogen implants and cultured in McCoy 5A medium supplemented with streptomycin sulfate $\left(100 \mathrm{U} \cdot \mathrm{mL}^{-1}\right)$, penicillin $\left(100 \mathrm{U} \cdot \mathrm{mL}^{-1}\right), \mathrm{L}$-glutamine $(2 \times$ $\left.10^{-3} \mathrm{M}\right)$, and androstenedione $\left(10^{-7} \mathrm{M}\right)$. The cells were incubated in $12 \times 75 \mathrm{~mm}$ polypropylene, round-bottomed Falcon culture tubes $\left(1 \times 10^{6}\right.$ cells $0.5 \mathrm{~mL}^{-1}$ medium $)$ at $37{ }^{\circ} \mathrm{C}$ in a humidified $5 \% \mathrm{CO}_{2}$ atmosphere for up to $48 \mathrm{~h}$ [13]. The medium was removed following incubation, and the remaining cells were processed for analysis of cAMPPDE activities and PDE4D protein levels.

In order to examine the regulation of PDE4D proteins over time, the cells were treated with and without FSH $\left(2 \mathrm{ng} \cdot \mathrm{mL}^{-1}\right)$ for $0,6,12,24$, and $48 \mathrm{~h}$. In order to examine the regulation of PDE4D protein levels by nitric oxide (NO), cGMP and PKB inhibitor (LY294002), the cells were treated for $6 \mathrm{~h}$ with medium alone (control), FSH ( $\left.2 \mathrm{ng} \cdot \mathrm{mL}^{-1}\right)$, and/or the NO donor DETA/ NO $\left(10^{-4} \mathrm{M}\right)$, (Bu2)-cGMP $\left(10^{-3} \mathrm{M}\right)$, LY294002 $\left(2.5 \times 10^{-5} \mathrm{M}\right)$. In the tube of FSH plus LY294002, LY294002 was added $1 \mathrm{~h}$ before the addition of FSH and then incubated another $5 \mathrm{~h}$. Protein was obtained from the cultured granulosa cells by disrupting the cell membrane with $1 \times$ RIPA lysis buffer (0.05 M Tris-HCl, pH 8; $0.15 \mathrm{M}$ $\mathrm{NaCl} ; 0.5 \% \mathrm{NP}-40 ; 20 \%$ glycerol; $0.025 \mathrm{M}$ benzamidine; $0.5 \mathrm{mg} \cdot \mathrm{mL}^{-1}$ leupeptine; $0.7 \mathrm{mg} \cdot \mathrm{mL}^{-1}$ pepstatin $\mathrm{A} ; 2 \mathrm{mg} \cdot \mathrm{mL}^{-1}$ aprotinin; $10 \mathrm{mg} \cdot \mathrm{mL}^{-1}$ trypsin inhibitor). The cells were then centrifuged for $15 \mathrm{~min}$ at 
$4{ }^{\circ} \mathrm{C}$ at $14000 \mathrm{rpm}$, and the supernatant was saved. Total protein concentrations were determined by the Bio-Rad protein assay using BSA standards and microplate absorbance readings at $595 \mathrm{~nm}$ [14]. Protein extracts were stored in liquid nitrogen until analysis. The experiments were repeated at least four times.

Additional studies were performed to examine the expression of PDE4D in the rat ovary. Four adult rats were euthanized and sacrificed at $1000 \mathrm{~h}$ of the proestrus day based on a smear check [15]. The ovary was snap-frozen and used for protein extraction and subsequent immunoblot analysis.

\subsection{Radioimmunoassays (RIA) of estradiol, cGMP, and cAMP}

Estradiol concentrations in the granulosa cell conditioned medium were determined by RIA $[16,17]$. The intra-coefficients of variation for estradiol determination in this laboratory were less than $9 \%$. Each cell culture experiment was analyzed within the same assay. Treatments were performed in triplicate, and each experiment was repeated at least three times.

The levels of cAMP and cGMP were measured using commercial RIA kits (Amersham Corp., Piscataway, NJ, USA) [18]. The minimum detection limits for cAMP and cGMP were 0.1 and $0.2 \mathrm{pmol} \cdot \mathrm{mL}^{-1}$ for nonacetylated samples; cross-reaction with cGMP or cAMP was less than $0.001 \%$. The intra- coefficients of variation for cAMP and cGMP were less than $6 \%$ and less than $8 \%$, respectively.

\subsection{PDE activity}

Cyclic nucleotide-PDE activity was determined by adding equal volumes of PDE reaction cocktail (100 mM Tris- $\mathrm{HCl} \mathrm{pH} 8.0$, $10 \mathrm{mM} \mathrm{MgCl} 2,2 \mu \mathrm{M}$ of either cAMP and $1 \times 10^{5} \mathrm{cpm}$ of $\left.\left[{ }^{3} \mathrm{H}\right] \mathrm{cAMP}\right)$ to the cell lysates $[19,20]$. Blank (background) control reactions were conducted in tubes containing a lysis buffer and a PDE reaction cocktail, without cell lysates. Additional controls were conducted using granulosa cell lysate that had been incubated in a boiling $\mathrm{H}_{2} \mathrm{O}$ bath for $5 \mathrm{~min}$.

\subsection{Immunoblot analyses of PDE4D}

Determination of PDE4D protein levels was performed by immunoblot analysis [13]. Briefly, the proteins were resolved by $7.5 \%$ polyacrylamide-SDS gel electrophoresis under reducing conditions. In each experiment, equal quantities of protein $(10 \mu \mathrm{g} / \mathrm{lane})$ prepared from each isolated granulosa cell or ovary sample were loaded, and then transferred onto nitrocellulose membranes (Hybond-C; Amersham Pharmacia, Piscataway, NJ, USA). The blots were blocked with 5\% milk-TBST (20 mM Tris-buffered saline, $0.05 \%$ Tween $20, \mathrm{pH}$ $7.5)$ at room temperature for $1 \mathrm{~h}$ and then incubated with or without diluted PDE4Dspecific antibody (Chemicon International, Temecula, CA, USA, diluted 1:1,000 with blocking solution) for $18 \mathrm{~h}$ at $4{ }^{\circ} \mathrm{C}$. The blots were then washed and incubated with horseradish peroxidase-conjugated goat anti-rabbit immunoglobulin $\mathrm{G}$, followed by washing and detection of immunoreactivity by chemiluminescence detection methods (Pierce Biotechnology, Rockford, IL, USA). Blots were then used to expose radiographic film to visualize immunoreactive signals. The density of bands on immunoblots was quantified using a Kodak imaging station systems (Eastman Kodak Company, New Haven, CT, USA). In addition, the blots were stripped and reprobed with an antibody against soluble guanylyl cyclase (sGC) alpha subunit (Sigma-Aldrich Inc, St Louis, Mo, USA) [13]. Following the exposition and image analysis, the intensity of PDE4D immunoreactive bands was normalized to the level of sGC alpha subunit proteins.

\subsection{Statistical analyses}

The results are expressed as the mean \pm SEM. Differences between treatment groups were determined by one-way or two-way 


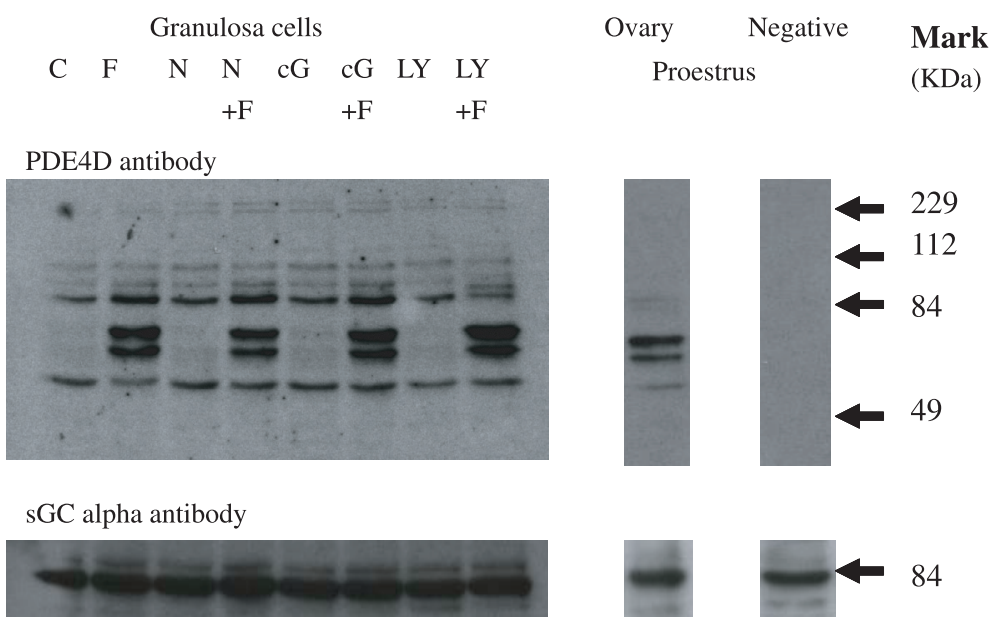

Figure 1. Changes in the expression of PDE4D in the granulosa cells and ovaries of rats. The granulosa cells obtained from immature rats were treated with medium alone (control), or FSH (F), cGMP analog $\left(\mathrm{Bu}_{2}\right)-\mathrm{cGMP}\left(10^{-3} \mathrm{M}\right)(\mathrm{cG}), \mathrm{F}+\mathrm{cG}$, the nitric oxide donor DETA/NO $(\mathrm{N}), \mathrm{F}+\mathrm{N}$, LY294002 (LY) for $6 \mathrm{~h}$ of culture. In the tube of F+LY, the granulosa cells were cultured with medium containing LY $1 \mathrm{~h}$, then added FSH for another $5 \mathrm{~h}$ of culture. The ovaries were obtained from adult rats at $1000 \mathrm{~h}$ of proestrus day. Protein homogenates from isolated granulosa cells ( $10 \mu \mathrm{g} / \mathrm{lane})$ and ovary $(10 \mu \mathrm{g} / \mathrm{lane})$ were fractionated on SDS-PAGE gels and transferred to nitrocellulose, followed by immunoblot analysis with antisera specific to PDE4D. For the negative control, immunoblot analysis was performed with omission of primary antisera. The migrating positions of molecular weight standards are shown on the right. In addition, the blots were stripped and reprobed with an antibody against soluble guanylyl cyclase (sGC) alpha subunit. Note: by using PDE4D specific antiserum, two predominant bands of approximately 70 and $80 \mathrm{kDa}$ appeared if treated with FSH in the granulosa cell blots, while these two bands were readily detectable in the proestrus ovaries of rats.

analysis of variance, followed by the Scheffe post hoc test. $P<0.05$ was considered statistically significant. Paired or unpaired twotailed Student $t$ test was used to detect significance between two series of data. $P<$ 0.05 was accepted as statistically significant.

\section{RESULTS}

\subsection{Expression of PDE proteins}

Immunoblot analysis of PDE proteins was performed using protein extracts of isolated granulosa cells from immature rats and homogenized ovaries from adult rats at the proestrus day. When the granulosa cell blots were incubated with a PDE4D spe- cific antibody, four bands were observed in the lanes of the control, cGMP, NO and LY294002 (PKB inhibitor), while two new predominant bands of approximately 80 and $70 \mathrm{kDa}$, which corresponded to the reported size of PDE4D, appeared after adding FSH (Fig. 1). There were no differences in density of two FSH stimulated bands on granulosa cell blots among the three cotreatment tubes of cells with FSH plus a NO generator or cGMP analog or LY294002 after quantification using a Kodak imaging station system (data not shown). When the ovary blots were incubated with the PDE4D antibody, two dominant bands of approximately 80 and $70 \mathrm{kDa}$ also appeared (Fig.1). If the primary antibody was omitted, both granulosa cell and ovary blots showed no bands (Fig. 1). 

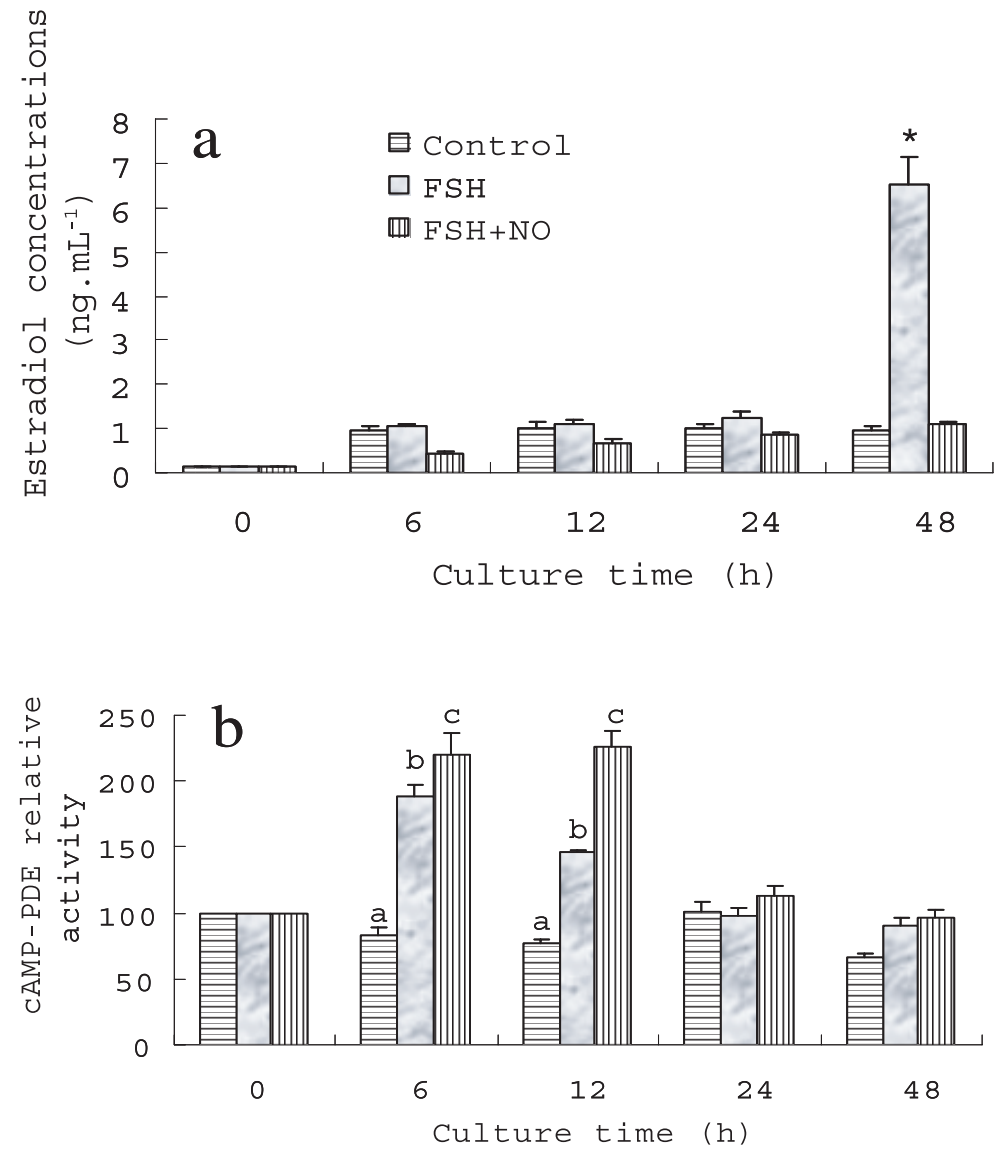

Figure 2. Medium estradiol $\left(\mathrm{E}_{2}\right)$ concentrations and cAMP-PDE relative activities after treatment of immature rat granulosa cells with medium alone (control), FSH $\left(2 \mathrm{ng} \cdot \mathrm{mL}^{-1}\right)$, the NO donor DETA/ NO $\left(10^{-4} \mathrm{M}\right)$, and/or $(\mathrm{Bu} 2)$-cGMP $\left(10^{-3} \mathrm{M}\right)$. Values are the mean \pm SEM for 4 repeats, $* P<0.05$ was considered statistically significant (Scheffe post hoc test and paired or unpaired two-tailed Student $t$ test).

\subsection{Activity of cAMP-specific PDE}

An activity assay of cAMP-specific PDE showed that isolated granulosa cells treated with medium alone displayed low cAMPPDE activity throughout $48 \mathrm{~h}$ of culture while those treated with FSH $\left(2 \mathrm{ng} \cdot \mathrm{mL}^{-1}\right)$ showed a marked increase in cAMP-PDE activity between 6 and $12 \mathrm{~h}$ of culture, followed by a decline thereafter. Cotreatment of cells with FSH plus a NO generator or
cGMP analog had no significant effect on cAMP-specific PDE activity (Fig. 2).

\subsection{Concentrations of estradiol, cGMP and $\mathrm{CAMP}$ in the culture medium}

Concentrations of estradiol in the conditioned medium from granulosa cells treated with FSH ( $\left.2 \mathrm{ng} \cdot \mathrm{mL}^{-1}\right)$ and/or FSH/NO displayed no change throughout $24 \mathrm{~h}$ of culture 

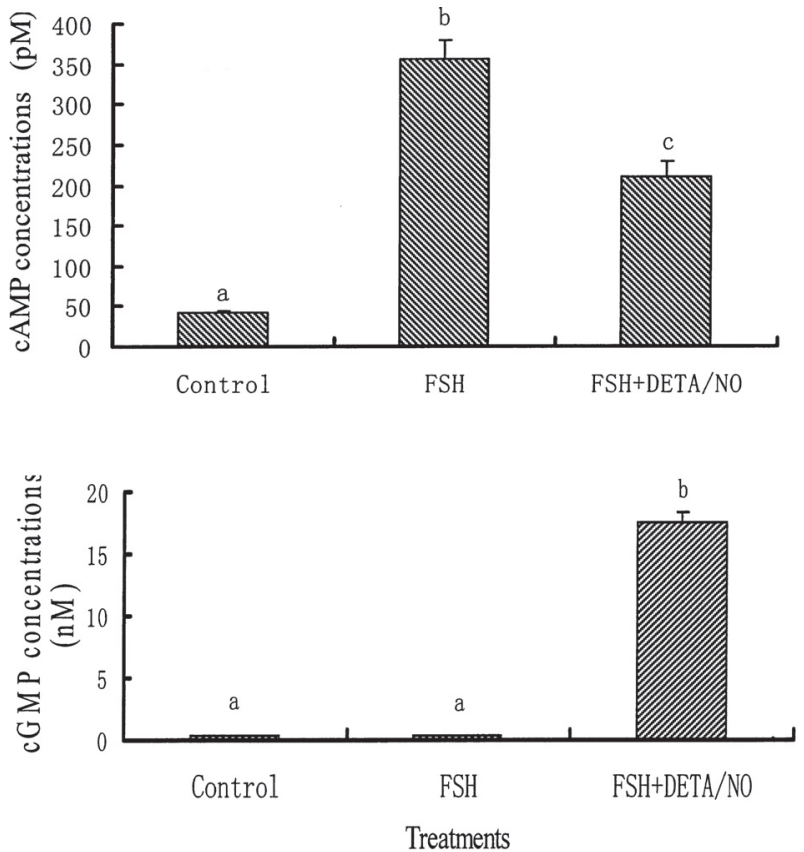

Figure 3. Medium concentrations of cAMP and cGMP after treatment of immature rat granulosa cells with medium alone (control), FSH $\left(2 \mathrm{ng} \cdot \mathrm{mL}^{-1}\right)$, and/or the NO donor DETA/NO $\left(10^{-4} \mathrm{M}\right)$ for $48 \mathrm{~h}$. Values are the mean \pm SEM for 4 repeats, $* P<0.05$ was considered statistically significant (Scheffe post hoc test and paired or unpaired two-tailed Student $t$ test).

while at $48 \mathrm{~h}, \mathrm{FSH}\left(2 \mathrm{mg} \cdot \mathrm{mL}^{-1}\right)$ resulted in a marked increase. We next examined the medium concentrations of cGMP and cAMP of $48 \mathrm{~h}$ (Fig. 2). The group treated with FSH displayed a significant increase in the concentration of cAMP and no change in cGMP concentrations while that co-treated with DETA/NO resulted in a marked increase in cGMP concentrations and an unmarked increase in cAMP concentrations (Fig. 3).

\section{DISCUSSION}

This study describes the activity of cAMPspecific PDE and expression of PDE4D in cultured immature rat granulosa cells. The development/maturation of granulosa cells is an essential stage during follicular development in the ovary. The cAMP-specific
PDE4 enzymes are encoded by four genes designated as PDE4A, B, C and D. Each gene exhibits multiple splice variants with common catalytic and $\mathrm{C}$-terminal regions, but is distinguished by its unique $\mathrm{N}$-terminal region. The 'long' PDE4 isozymes are characterized by two upstream conserved regions 1 and 2 (UCR1 and UCR2, respectively) [21-25]. In the current study, isolated immature rat granulosa cells treated with FSH expressed two new bands that corresponded to the reported size of PDE4D. These two bands were also expressed in the proestrus ovaries of rats. It is reported that PDE4 is the main type of PDE in the rat granulosa cells [26-28]. Taken together, the molecular weight, species and cAMP inducibility of the FSH responsive PDE suggest that these two regulated bands are PDE4D. 
It is well known that cAMP plays a critical role in the maturation of rat granulosa cells. In the ovaries, changes in cAMP-specific PDE levels result in changes in cAMP and estradiol levels, thus modulating ovarian functions [29-31]. The results of our present study demonstrate that FSH induces a transient, time-dependent increase in PDE4D protein levels, corresponding to observed changes in PDE4 activity. The induction of PDE4D by FSH might logically serve to limit the duration and magnitude of the cAMP-mediated stimulation of steroidogenesis. These findings indicate that the stimulatory effects of FSH on PDE4 activity are associated with increased levels of PDE4D protein, suggesting effects on protein synthesis rather than merely functional activation of existing proteins.

In addition to $\mathrm{FSH}$, other factors and second messengers also influence granulosa cell function. The results of our present study showed that estradiol levels in medium are decreased by treatment of granulosa cells with NO. This was consistent with the previous report [9]. It is reported that cAMP levels are also decreased by the treatment of granulosa cells with cGMP and NO [9, 10]. Therefore, our current studies also examined the influence of NO and cGMP on PDE4D protein levels in cultured rat granulosa cells. Cotreatment of granulosa cells with FSH plus a NO generator or cGMP analog had no effect on PDE4D levels indicating that the inhibitory effects of NO and cGMP on FSH-stimulated cAMP production do not appear to involve altered expression of PDE4D, and do not reflect increased cAMP-PDE activity.

$\mathrm{PKB}$ is a general mediator of cell survival and protection from apoptosis [32, 33]. It is not known how blockage of the PKB pathway influences the PDE proteins in cultured rat granulosa cells. Several previous studies showed that LY294002 at $25 \mu \mathrm{M}$ can block the PI3K/PKB pathway $[34,35]$. The results of our present study indicate that this PKB indirect inhibitor did not affect the expression of PDE4D in rat granulosa cells induced by FSH at $25 \mu \mathrm{M}$. This may imply that the regulation of PDE4D by FSH is mainly through pathways other than the PKB pathway.

In summary, the findings of the present study indicate that the increased cAMPPDE activity in response to FSH is mainly related to changes in PDE4D protein levels. Additionally, the inhibitory effects of NO on cAMP accumulation in rat granulosa cells are not mediated through the increased cAMP-PDE activity.

\section{ACKNOWLEDGEMENTS}

We express our gratitude to Dr Brian K. Petroff of the University of Kansas Medical Center, Kansas City, Kansas 66103, USA for reading the original manuscript and offering valuable suggestions.

\section{REFERENCES}

[1] Beavo JA. Cyclic nucleotide phosphodiesterases: functional implications of multiple isoforms. Physiol Rev 1995, 75: 725-748.

[2] Soderling SH, Beavo JA. Regulation of cAMP and cGMP signaling: new phosphodiesterases and new functions. Curr Opin Cell Biol 2000, 12: $174-179$.

[3] Michaeli T, Bloom TJ, Martins T, Loughney K, Ferguson K, Riggs M, Rodgers L, Beavo JA, Wigler M. Isolation and characterization of a previously undetected human cAMP phosphodiesterase by complementation of cAMP phosphodiesterase-deficient Saccharomyces cerevisiae. J Biol Chem 1993, 268: 12925-12932.

[4] Jin SL, Richard FJ, Kuo WP, D'Ercole AJ, Conti M. Impaired growth and fertility of cAMP-specific phosphodiesterase PDE4Ddeficient mice. Proc Natl Acad Sci USA 1999, 96: 11998-12003.

[5] Park JY, Richard F, Chun SY, Park JH, Law E, Horner K, Jin SL, Conti M. Phosphodiesterase regulation is critical for the differentiation and pattern of gene expression in granulosa cells of the ovarian follicle. Mol Endocrinol 2003, 17: 1117-1130.

[6] Crossthwaite AJ, Valli H, Williams RJ. Inhibiting Src family tyrosine kinase activity blocks 
glutamate signalling to ERK $1 / 2$ and Akt/PKB but not JNK in cultured striatal neurones. J Neurochem 2004, 88: 1127-1139.

[7] Filippa N, Sable CL, Filloux C, Hemmings B, Van Obberghen E. Mechanism of protein kinase B activation by cyclic AMP-dependent protein kinase. Mol Cell Biol 1999, 19: 49895000

[8] Mei FC, Qiao J, Tsygankova OM, Meinkoth JL, Quilliam LA, Cheng X. Differential signaling of cyclic AMP: opposing effects of exchange protein directly activated by cyclic AMP and cAMP-dependent protein kinase on protein kinase B activation. J Biol Chem 2002 , 277: 11497-11504.

[9] Ishimaru RS, Leung K, Hong L, LaPolt PS. Inhibitory effects of nitric oxide on estrogen production and cAMP levels in rat granulosa cell cultures. J Endocrinol 2001, 168: 249_ 255.

[10] LaPolt PS, Hong LS. Inhibitory effects of superoxide dismutase and cyclic guanosine 3',5'-monophosphate on estrogen production in cultured rat granulosa cells. Endocrinology 1995, 1362: 5533-5539.

[11] Ignarro LJ. Signal transduction mechanisms involving nitric oxide. Biochem Pharm 1991, 41: 485-490.

[12] Bredt DS, Snyder SH Nitric oxide: a physiological messenger molecule. Ann Rev Biochem 1994, 63: 175-195.

[13] Shi F, Stewart RL, Perez E, Chen JY, LaPolt PS. Cell-specific expression and regulation of soluble guanylyl cyclase alpha and beta subunits in the rat ovary. Biol Reprod 2004, 70: 1552-1561.

[14] Bradford MM. A rapid and sensitive method for the quantitation of microgram quantities of protein utilizing the principle of protein-dye binding. Anal Biochem 1976, 72: 248-254.

[15] Liu G, Shi F, Blas-Machado U, Duong Q, Davis VL, Foster WG, Hughes CL. Ovarian effects of high lactose diet in the female rat. Reprod Nutr Dev 2005, 45: 185-192.

[16] Shi F, Mochida K, Matsuda J, Ogura A, Suzuki O, Ozawa M, Watanabe G, Suzuki AK, Taya K. Ovarian localization of immunoglobulin $G$ and inhibin alpha-subunit in guinea pigs following passive immunization against the inhibin alpha-subunit. J Reprod Dev 2000, 46: 293-299.

[17] Shi F, Ozawa M, Komura H, Yang P, Trewin AL, Hutz RJ, Watanabe G, Taya K. Secretion of ovarian inhibin and its physiologic roles in the regulation of follicle-stimulating hormone secretion during the estrous cycle of the female guinea pig. Biol Reprod 1999, 60: 78-84.

[18] Shi F, Zhan Y, Ruan H, Hong Q, Xu Z. Studies on the mechanism of network of immune-neuroendocrine interaction against infectious bursal disease virus in broilers. Chinese J Vet Sci 1996, 16: 333-337 (in Chinese).

[19] Thompson JW, Appleman MM. Multiple cyclic nucleotide phosphodiesterase activities from rat brain. Biochemistry 1971, 10: 311315

[20] Rob JZ, Jennifer KW. Effects of hepatocyte growth factor on cyclic nucleotide-dependent signaling and steroidogenesis in rat ovarian granulosa cells in vitro. Biol Reprod 2002, 67: 454-459.

[21] Beard MB, Olsen AE, Jones RE, Erdogan S, Houslay MD, Bolger GB. UCR1 and UCR2 domains unique to the cAMP-specific phosphodiesterase family form a discrete module via electrostatic interactions. J Biol Chem 2000, 275: 10349-10358.

[22] Bolger GB. Molecular biology of the cyclic AMP-specific cyclic nucleotide phosphodiesterases: a diverse family of regulatory enzymes. Cell Signal 1994, 6: 851-859.

[23] Hill EV, Houslay MD, Baillie GS. Investigation of extracellular signal-regulated kinase 2 mitogen-activated protein kinase phosphorylation and regulation of activity of PDE4 cyclic adenosine monophosphate-specific phosphodiesterases. Methods Mol Biol 2005, 307: 225-237.

[24] MacKenzie SJ, Baillie GS, McPhee I, Bolger GB, Houslay MD. ERK2 mitogen-activated protein kinase binding, phosphorylation, and regulation of the PDE4D cAMP-specific phosphodiesterases. The involvement of $\mathrm{COOH}$-terminal docking sites and $\mathrm{NH} 2$-terminal UCR regions. J Biol Chem 2000, 275 : 16609-16617.

[25] Richter W, Conti M. Dimerization of the type 4 cAMP-specific phosphodiesterases is mediumted by the upstream conserved regions (UCRs). J Biol Chem 2002, 277: 4021240221 .

[26] McKenna SD, Pietropaolo M, Tos EG, Clark A, Fischer D, Kagan D, Bao B, Chedrese PJ, Palmer S. Pharmacological inhibition of phosphodiesterase 4 triggers ovulation in folliclestimulating hormone-primed rats. Endocrinology 2005, 146: 208-214.

[27] Thomas RE, Armstrong DT, Gilchrist RB. Differential effects of specific phosphodiesterase isoenzyme inhibitors on bovine oocyte 
meiotic maturation. Dev Biol 2002, 244: 215225.

[28] Tsafriri A, Chun SY, Zhang R, Hsueh AJ, Conti M. Oocyte maturation involves compartmentalization and opposing changes of cAMP levels in follicular somatic and germ cells: studies using selective phosphodiesterase inhibitors. Dev Biol 1996, 178: 393-402.

[29] Kofinas AD, Rose JC, Koritnik DR, Meis PJ. Progesterone and estradiol concentrations in nonpregnant and pregnant human myometrium: Effect of progesterone and estradiol on cyclic adenosine monophosphate-phosphodiesterase activity. J Reprod Med 1990, 35: 1045-1050.

[30] Lacasa D, Agli B, Giudicelli Y. Hormonal activation of the cGMP-inhibited low-Km cyclic AMP phosphodiesterase of rat adipocytes from different sites: influence of ovariectomy. Biochim Biophys Acta 1992, 1136: 99-104.

[31] Zachow RJ, Woolery JK. Effects of hepatocyte growth factor on cyclic nucleotidedependent signaling and steroidogenesis in rat ovarian granulosa cells in vitro. Biol Reprod 2002, 67: 454-459.

[32] Hemmings BA. Akt signaling: linking membrane events to life and death decisions. Science 1997, 275: 628-630.

[33] Coffer PJ, Jin J, Woodgett JR. Protein kinase B (c-Akt): a multifunctional mediumtor of phosphatidylinositol 3-kinase activation. Biochem J 1998, 335: 1-13.

[34] Gonzalez-Robayna IJ, Falender AE, Ochsner S, Firestone GL, Richards JS. Follicle-Stimulating hormone (FSH) stimulates phosphorylation and activation of protein kinase $B$ (PKB/Akt) and serum and glucocorticoidlnduced kinase (Sgk): evidence for A kinaseindependent signaling by FSH in granulosa cells. Mol Endocrinol 2000, 14:1283-1300.

[35] Richards JS, Sharma SC, Falender AE, Lo YH. Expression of FKHR, FKHRL1, and AFX genes in the rodent ovary: evidence for regulation by IGF-I, estrogen, and the gonadotropins. Mol Endocrinol 2002, 16: 580599. 